\title{
Estimation of aloin concentration in Aloe vera L. (Aloe barbadensis Mill.) by mathematical modeling
}

Estimación de la concentración de aloína en Aloe vera L. (Aloe barbadensis Mill.) mediante modelización matemática

Estimativa da concentração de aloína em Aloe vera L. (Aloe barbadensis Mill.) por modelagem matemática

Tamara Molero Paredes ${ }^{1,3^{*}}$ (a) (1)

Said Kas-Danouche ${ }^{2,3}$

Rev. Fac. Agron. (LUZ). 2022, 39(1): e223913

ISSN 2477-9407

DOI: https://doi.org/10.47280/RevFacAgron(LUZ).v39.n1.13

\section{Food Technology}

Associate editor: Dra. Gretty Ettienne
${ }^{1}$ Universidad del Zulia. Facultad de Humanidades y Educación. Departamento de Biología. Venezuela.

${ }^{2}$ Universidad de Oriente. Escuela de Ciencias. Departamento de Matemática. Laboratorio de Matemática Aplicada para la Industria. Venezuela.

${ }^{3}$ Universidad Adventista Dominicana. Facultad de Humanidades. Escuela de Ciencias. República Dominicana.

Recibido: 10-06-2021

Aceptado: 11-11-2021

Published: 03-02-2022

\section{Keywords:}

Aloin

Concentration

Estimate

Mathematical modeling

\begin{abstract}
Aloin is one of the secondary metabolites that gives plants of the genus Aloe spp. their healing properties. The concentration of aloin is related to the fresh mass and, its industrial purification involves laboratory processes that add extra costs to its commercialization. The objective of this research was to mathematically modelize the estimation of the aloin concentration in A. vera $\mathrm{L}$. from the fresh mass. The theory of discrete perfect least squares approximations was used, considering linear and exponential approximation functions. For the tabulation of the data, the option of class mark and the average of the values were used. The analyses of the approximations indicate that the exponential curves approximate the data better (with $\mathrm{R}^{2}=75 \%$ and $82 \%$ for the two options, respectively) than the straight lines (with $\mathrm{R}^{2}=65 \%$ and $70 \%$ for the two options, respectively). The use of these approximations is recommended to estimate the concentration of aloin in A. vera plants based on their fresh mass, facilitating the measurement of this secondary metabolite, and minimizing costs in the industrialization process.
\end{abstract}




\section{2-6 | Rev. Fac. Agron. (LUZ). 2022, 39(1): e223913. January - March. ISSN 2477-9407.}

\section{Resumen}

La aloína es uno de los metabolitos secundarios que le otorga a las plantas del género Aloe spp., sus propiedades curativas. La concentración de aloína está relacionada con la masa fresca y su purificación industrial requiere procesos de laboratorio que agrega costos extras a la comercialización. El objetivo de este trabajo fue modelizar matemáticamente la estimación de la concentración de aloína en $A$. vera L., a partir de la masa fresca. Se usó la teoría de aproximaciones de mínimos cuadrados perfectos discretos, considerando la función de aproximación lineal y exponencial. Para la tabulación de los datos se usaron las opciones de marca de clase y el promedio de los valores. Los análisis de las aproximaciones indican que las curvas exponenciales aproximan mejor los datos (con un $\mathrm{R}^{2}=75 \%$ y $82 \%$ para las dos opciones, respectivamente) que las líneas rectas (con un $\mathrm{R}^{2}=65 \%$ y $70 \%$ para las dos opciones, respectivamente). El uso de estas aproximaciones se recomienda para la estimación de la concentración de aloína en $A$. vera en función a su masa fresca, facilitando la medición de este metabolito secundario y minimizando gastos en el proceso de industrialización.

Palabras clave: aloína; concentración; estimación; modelización matemática.

\section{Resumo}

Aloin é um dos metabólitos secundários que dá às plantas do gênero Aloe spp., suas propriedades curativas. A concentração de aloin está relacionada à massa fresca e sua purificação industrial requer processos laboratoriais que agregam custos extras à comercialização. O objetivo deste trabalho foi modelar matematicamente a estimativa da concentração de aloína em $A$. vera $\mathrm{L}$. a partir da massa fresca. Foi utilizada a teoria das aproximações de mínimos quadrados perfeitos discretos, considerando a função de aproximação linear e exponencial. Para a tabulação dos dados, foram utilizadas as opções de marcação da classe e a média dos valores. As análises das aproximações indicam que as curvas exponenciais aproximam melhor os dados $\left(\operatorname{com} \mathrm{R}^{2}=\right.$ $75 \%$ e $82 \%$ para as duas opções, respectivamente) do que as retas (com $\mathrm{R}^{2}=65 \%$ e $70 \%$ para as duas opções, respectivamente) . O uso dessas aproximações é recomendado para estimar a concentração de aloína em $A$. vera com base em sua massa fresca, facilitando a mensuração desse metabólito secundário e minimizando custos no processo de industrialização.

Palabras-chave: aloin; concentração; estimativa; modelagem matemática.

\section{Introduction}

Aloe vera $\mathrm{L}$ (= Aloe barbadensis $\mathrm{M} .=$ sábila or aloe) is cultivated all over the world for agricultural, medicinal, cosmetic and decorative purposes, being its place of origin the northern limits of the Arabian Peninsula, located in southern Africa (Klopper \& Smith, 2013; Pandey \& Singh, 2016). Aloes have been named since ancient times because in the Bible it is said that they were employed as perfumes and in the funerary arts. Numerous studies show that the genus Aloe was subjected to strong environmental processes diversifying by speciation, giving rise to the extraordinary diversity of species known today (Klopper \& Smith, 2013; Deng-Feng et al., 2019).
The therapeutic and medicinal properties of $A$. vera as a pain reliever, analgesic, bactericide, moisturizer, emollient, antiinflammatory, antitumor, among others, is well documented, thanks to the metabolites that are synthesized by secondary routes (Mahor $\&$ Ali, 2016). One of them is aloin, considered the active compound of these plants, which is found in their exudates with a defensive function and is the taxonomic marker of the genus Aloe spp, it also has a laxative action in humans, so the consumption of supplements based on this compound can have toxic effects if ingested in large quantities (Minjares \& Femenia, 2019).

This compound is found especially in the acíbar or juice of the leaves and when extracted from this yellow liquid and after a drying process, it appears as a yellow powder of bitter taste, product of its chemical structure, characterized by being a glycoside formed from an anthraquinone (genin) linked with a sugar. Aloin can be presented in two different isomeric forms, aloin-A (barbaloin) and aloin-B (isobarbaloin), in such a way that some of them can produce one of the two types or present a mixture of them. Likewise, their concentration may vary according to the species, age of the plants, region and time of collection (Kaparakou et al., 2020).

Depending on the Aloe spp. product to be offered on the market (medicines, cosmetics, beverages, food, etc.), it is necessary to determine the aloin concentration and ensure that it complies with international requirements. In this sense, the European Union established that, in the case of foods and medicines, the maximum limit of aloin must be $0.1 \mathrm{mg} \cdot \mathrm{kg}^{-1}$ (EEC 88/388) (Official Journal of the European Communities, 1988). The same regulation was established by the International Aloe Science Council for the United States. In the cosmetic industry, there is no direct consumption of any part of the plant, therefore, the use of both acíbar and gel, either concentrated or powdered, is accepted (Pedroza et al., 2009). The aloin concentration is more accurately measured by chromatographic methods; however, these methods of analysis are laborious and expensive to apply at the industrial level, in which large volumes of plant material are handled. Therefore, it is convenient to establish an alternative that allows estimating the aloin concentration in A. vera L., considering other variables that are easy to handle for both the producer and the industry, for example, fresh and dry mass of the plant, which allows knowing the aloin content without the need of resorting to laborious laboratory protocols.

Mathematical modeling allows to test the consequence of changes in a system due to it describes phenomena using the language of mathematics. When using a mathematical model, the first step is to identify the significant variables in the system, which will be included in the model. The second step is related to the determination of the equations that govern the system that allow predictions to be made. Although mathematics offers the facility of proving general results, these critically depend on the formulation of the equations used. Small changes in the structure of the equations can involve enormous changes in the mathematical methods.

The use of simulation and prediction models has become popular in agriculture and has become a tool both for research, as well as for producers, technical consultants and industrialists, who can now mathematically define the best crop management practice in certain situations (FAUBA, 2018). In addition, modeling has been used to improve the effects of industrialization processes of agricultural products. In this regard, Martinez et al. (2017) optimized the protocol for removing aloin from $A$. vera gel by employing three input variables: temperature, agitation time, and activated carbon concentration. The 
results showed that the latter two variables exerted a significant action on the removal of aloin from $A$. vera gel.

Due to the mathematical modeling is an important tool for the calculation of the yields of crops of interest, the objective of the present research was to apply the mathematical modeling to estimate the aloin concentration in $A$. vera $\mathrm{L}$. starting from the fresh mass values of the plant.

\section{Materials and methods}

\section{Plant material}

Ten plants of $A$. vera were randomly collected in seven commercial farms located in the western region of Venezuela, three in the central zone of Falcon state (farm 1: $11^{\circ} 03^{\prime} 13^{\prime \prime} \mathrm{N} 69^{\circ} 45^{\prime} 07^{\prime \prime} \mathrm{W}$, farm 2: $11^{\circ} 29^{\prime} 16^{\prime \prime} \mathrm{N} 69^{\circ} 21^{\prime} 08^{\prime \prime} \mathrm{W}$ and farm 3: $11^{\circ} 14^{\prime} 26^{\prime \prime} \mathrm{N}$ $70^{\circ} 06^{\prime} 08^{\prime \prime} \mathrm{W}$ ), another located in northern Falcon state (farm 4: $11^{\circ} 52^{\prime} 22^{\prime \prime} \mathrm{N} 69^{\circ} 59^{\prime} 18^{\prime \prime} \mathrm{W}$ ) and three in northern Zulia state (farm 5: $10^{\circ} 51^{\prime} 34^{\prime \prime} \mathrm{N} 71^{\circ} 45^{\prime} 44^{\prime \prime} \mathrm{W}$, farm 6: $10^{\circ} 54^{\prime} 56^{\prime \prime} \mathrm{N} 71^{\circ} 49^{\prime} 38^{\prime \prime} \mathrm{W}$ and farm 7: $10^{\circ} 40^{\prime} 14^{\prime \prime} \mathrm{N} 71^{\circ} 31^{\prime} 36^{\prime \prime} \mathrm{W}$ ). The collection was carried out between the months of January to March, which corresponds to the dry season in the country.

According to Ewel and Madriz (1976), the climates of these sites correspond to a thorny-tropical forest and very dry tropical forest, with altitudes of 0-200 mamsl, with temperatures above $25{ }^{\circ} \mathrm{C}$ and rainfall between 250 and $800 \mathrm{~mm}$ per year, with high solar radiation.

Plants in good health and with at least 10 leaves and approximately $35 \mathrm{~cm}$ in height were selected. Subsequently, they were taken to the nursery of the Facultad de Humanidades de la Universidad Del Zulia, and they were sown in plastic containers with equal proportions of sand and organic fertilizer, to achieve vegetative reproduction.

Approximately 10 months after sowing, three sprouts from each mother plant, for a total of 210 plants evaluated. Later, they were transplanted into new plastic containers and were irrigated once a week.

\section{Determination of fresh mass and aloin concentration}

When the sprouts were six (6) months old, fresh mass (PF) and aloin concentration (CA) were determined by high performance liquid chromatography (HPLC). For this purpose, each one was sanitized and subsequently weighed on a commercial balance. Then, they were homogenized in a blender and this content was stored in hermetically sealed bags in a $-18^{\circ} \mathrm{C}$ freezer. This material was freeze-dried in a LABCONCO LYLH-LOCK 6 equipment for 72 hours until it reached complete dehydration. The powder was sent to the chromatography laboratory of the Facultad de Agronomia de la Universidad Del Zulia, (Venezuela) to measure CA according to the protocol previously established by Molero et al. (2016). The CA value corresponds to the amount of grams per $100 \mathrm{~g}$ of fresh plant mass.

\section{Data tabulation}

It was planned to use the theory of approximations, to find the function that best fit the collected data. However, it was observed that there were data with the same abscissa, which clearly indicates that they did not represent a function. For the development of the approximation theory, it is assumed that it starts with a function (Epperson, 2021; Chapra \& Canales, 2015; Burden \& Faires, 2011) which is desired to be approximate or, in its defect, a set of data (which represent a function) to which is required to approximate by means of an approximation function. In view of this, it was proceeded to tabulate the data in classes. The procedure used to tabulate the data was the following: per each plant analyzed of Aloe vera, $\mathrm{PF}$ value was corresponded to the CA. To describe the classes, the Herbert Sturges' Rule was used (González, 2017; Sturges, 1926).

$$
k=1+3.322 \log (\mathrm{n}),
$$

where

$k$ is the number of intervals to be formed and $\mathrm{n}$ is the total number of data collected or, in other words, the total number of samples taken. To define the classes it is necessary to know the range that each class should have. The range is defined, using the number $k$ from the Herbert Sturges' Rule (González, 2017; Sturges, 1926), as follows:

$$
\text { Range }=\left(\text { Max }\{\text { Fresh } \text { mass }\}-\text { Min }\left\{\text { Fresh } \text { mass }_{\}}\right\}\right) / k \text {, }
$$

where

Max $\{$ Fresh mass $\}$ is the maximum value and Min $\{$ Fresh mass $\}$ is the minimum value of the set of all the values and data collected from the PF. The Sturges' rule is a criterion that helps to formally determine the number of classes needed to represent a data set (González, 2017; Sturges, 1926).

Once the classes were defined, it was proceeded to determine the best representative of each class, discriminating between the class mark and the average of all the fresh masses measured that fall into each class. We proceeded, then, to work with the two possibilities as options for the tabulation of the PF, denoted by $x_{i}$, to then make comparisons and see which of the two options produces a better approximation.

These two options were used for the approximation functions proposed in the following paragraphs.

\section{Approximation theory}

The theory of discrete least squares approximations was used to find the functions that best fit the tabulated data. This theory was used because it allows finding the function that "best" fits a given data set (Epperson, 2021; Chapra \& Canales, 2015; Burden \& Faires, 2011). The two options, described in the previous section, were considered for both a linear approximation function and an exponential approximation function.

For the case of the linear function, the objective is to find the line that best approximates the tabulated data, with which a function of the form should be found (Burden \& Faires, 2011):

where

$$
\mathrm{y}=\mathrm{a} \cdot \mathrm{x}+\mathrm{b}
$$

$$
a=\frac{m \sum_{i=1}^{m} x_{i} y_{i}-\left(\sum_{i=1}^{m} x_{i}\right)\left(\sum_{i=1}^{m} y_{i}\right)}{m \sum_{i=1}^{m} x_{i}^{2}-\left(\sum_{i=1}^{m} x_{i}\right)^{2}}
$$

represents the slope of the linear function, and,

$$
b=\frac{\left(\sum_{i=1}^{m} x_{i}{ }^{2}\right)\left(\sum_{i=1}^{m} y_{i}\right)-\left(\sum_{i=1}^{m} x_{i} y_{i}\right)\left(\sum_{i=1}^{m} x_{i}\right)}{m \sum_{i=1}^{m} x_{i}{ }^{2}-\left(\sum_{i=1}^{m} x_{i}\right)^{2}},
$$

represents the intercept of this function with the y-axis. Also, it is considered that $x_{i}$ and $y_{i}$ correspond to the fresh mass and the aloin concentration, respectively, for each $i-t h$ class, and $m$ is the number of classes corresponding to $k$ in the previous section.

In the second case, it was intended to find the exponential curve that best approximates the tabulated data, with which a function of the form should be found (Burden \& Faires, 2011): 
4-6 | Rev. Fac. Agron. (LUZ). 2022, 39(1): e223913. January - March. ISSN 2477-9407.

where

$$
y=b e^{a x}
$$

$$
a=\frac{m \sum_{i=1}^{m} x_{i} \ln \left(y_{i}\right)-\left(\sum_{i=1}^{m} x_{i}\right)\left(\sum_{i=1}^{m} y_{i}\right)}{\sum_{i=1}^{m} x_{i}^{2}-\left(\sum_{i=1}^{m} x_{i}\right)^{2}}
$$

represents the coefficient of the argument of the exponential function, and

$$
\ln (b)=\frac{\left(\sum_{i=1}^{m} x_{i}{ }^{2}\right)\left(\sum_{i=1}^{m} \ln \left(y_{i}\right)\right)-\left(\sum_{i=1}^{m} x_{i} \ln \left(y_{i}\right)\right)\left(\sum_{i=1}^{m} x_{i}\right)}{m \sum_{i=1}^{m} x_{i}{ }^{2}-\left(\sum_{i=1}^{m} x_{i}\right)^{2}},
$$

where $\mathrm{b}$ represents the degree of the slope of the exponential curve, considering that $x_{i}$ and $y_{i}$ correspond to the fresh mass and the aloin concentration, respectively, for each $i-t h$ class, and $m$ is the number of classes that correspond to $k$ in the previous section.

To calculate the linear and exponential approximations of the data, the Excel spreadsheet for Windows environment was used (Charte 2016) and they were corroborated with InfoStat statistical package (Di Rienzo et al., 2011). The comparisons between the four approximations were carried out using the coefficient of determination $\left(\mathrm{R}^{2}\right)$.

\section{Results and discussion}

As it was mentioned in materials and methods, the number of the data collected was $\mathrm{n}=210$ for each characteristic studied, therefore, from the Herbert Sturges Rule it is deduced that $k \approx 9$. From the collected numbers, the maximum and minimum PF values were $523 \mathrm{~g}$ and $100 \mathrm{~g}$ respectively, and the average of all the PF data was $252.2 \mathrm{~g}$. In this sense, the range is approximately equal to 47 , which defines PF.

Once the classes were defined, the CA data were classified into each class. The maximum and minimum $\mathrm{CA}$ values were $0.03 \mathrm{~g}$ and $6.771 \mathrm{~g} .100^{-1} \mathrm{~g}$ of PF, respectively, with an CA average value of $1.242 \mathrm{~g}$.

Table 1 shows the two options proposed in the methodology for PF; the first option, calculating the class mark in each class, and the second option, calculating the fresh mass average of each class using all the collected values corresponding to each particular class. The aloin concentration average for each class is also included.

Table 1. Distribution of aloin concentration with respect to fresh mass (PF) classes in Aloe vera $\mathrm{L}$.

\begin{tabular}{clccc}
\hline & PF Classes & x1-PF marks & x2-Prom. PF Class & y-Prom. CA. \\
\hline 1 & $100-147$ & 123.5 & 117.3 & 0.93 \\
2 & $147-194$ & 170.5 & 174.9 & 0.93 \\
3 & $194-241$ & 217.5 & 215.2 & 1.34 \\
4 & $241-288$ & 264.5 & 259.6 & 1.54 \\
5 & $288-335$ & 311.5 & 310.0 & 1.60 \\
6 & $335-382$ & 358.5 & 357.3 & 1.82 \\
7 & $382-429$ & 405.5 & 400.4 & 2.93 \\
8 & $429-476$ & 452.5 & 446.8 & 2.75 \\
9 & $476-523$ & 499.5 & 520.0 & 6.77 \\
& Total Sum: & 2803.5 & 2801.6 & - \\
\hline
\end{tabular}

The results of the linear and exponential approximations for the two options are presented below.

Results for the approximations by linear function

For this case it was obtained:

$$
\mathrm{y}=0.011443 \mathrm{x}-1.2754
$$

for the first option (class mark) and,

$$
y=0.011509 x-1.2935 \text {, }
$$

for the second option (averages of the CA values in each class). Figure 1 shows the linear approximations of the aloin concentration. The validation of these results with the InfoStat software showed that: $a=0.01$ and $b=-1.28$, which are clearly rounded values of those calculated for the first linear approximation $(\mathrm{a}=0.011443$ and $\mathrm{b}=-1.2754)$.

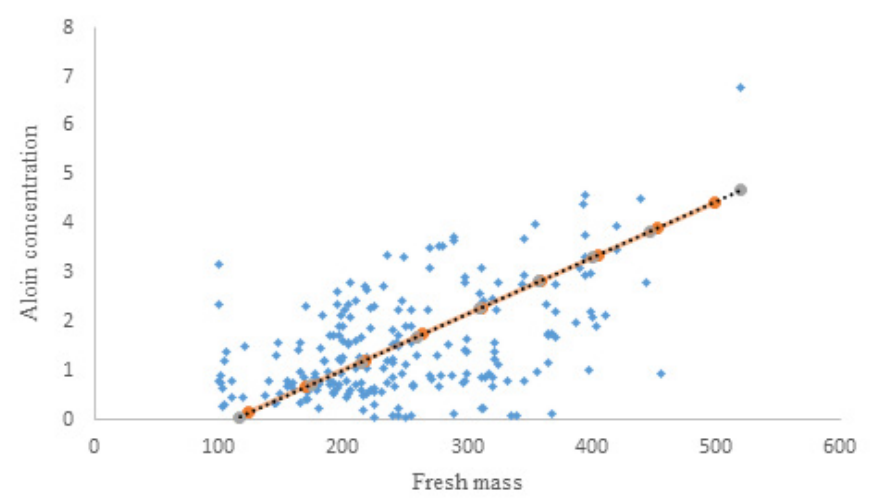

Figure 1. Linear approximations of aloin concentration

The red solid line represents the first of the linear approximation equations found, and the black dotted line corresponds to the second one. It can be seen that practically both lines overlap.

Results for the approximations by exponential function

For this case of approximation by exponential function, the following results were obtained.

$$
\mathrm{y}=0.44886 \mathrm{e}^{0.00458 \mathrm{x}}
$$

for the first option (class marks) and,

$$
\mathrm{y}=0.45896 \mathrm{e}^{0.00452 \mathrm{x}}
$$

for the second option (averages of the CA values in each class). Figure 2 shows the two corresponding curves to the calculations performed for the approximations of aloin concentration by exponential functions.

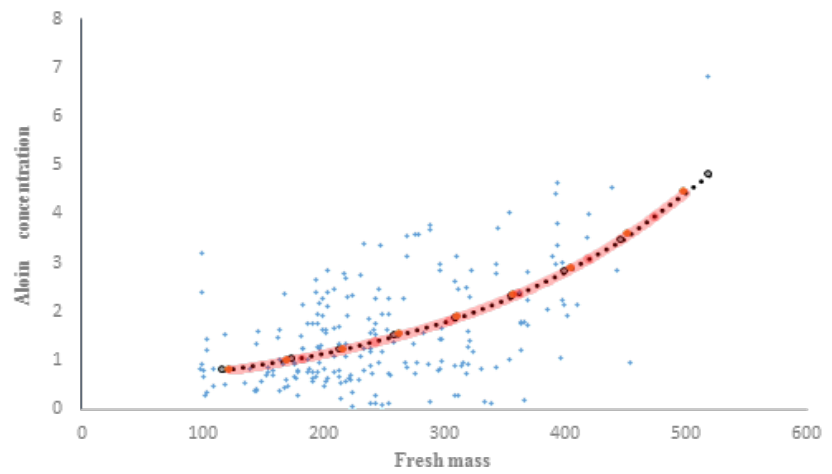

Figure 2. Exponential approximations of aloin concentration.

The red solid curve represents the first of the exponential approximation equations found and corresponds to the first option (class marks). The black dotted curve corresponds to the second option (CA averages). It can be seen that practically both exponential curves are overlapping. 
The concentration of aloin depends on several factors and for the industrialization of commercial aloe vera-based products, it is necessary to quantify the CA data and other plant components in order to meet the demands and specifications required by international standards.

When observing the graphs of the mathematical models obtained, both linear (figure 1) and exponential (figure 2), there is no noticeable difference between the two straight lines or between the two exponential curves, which correspond to the two tabulation options. What is observed is that both straight lines overlap, and both exponential curves overlap. In view of this, the coefficient of determination, $\left(\mathrm{R}^{2}\right)$, was calculated for each of the models to analyze their behavior with respect to the data. The coefficient of determination is a statistic that determines the quality of the model to replicate the results, and the proportion of variation in the results that can be explained by the model (Steel \& Torrie, 1960). It is used in the context of a statistical model whose main purpose is to predict future results or to test a hypothesis. But first, we proceeded to validate the models using ANOVA; that is, to test the three assumptions (Martinez et al., 2021). The first assumption requires that the residuals approximate a normal distribution. In figure 3 ( $a$ and $b$ ), it is observed that they do not have exactly a normal distribution. However, since in this research the size of the groups is equal to each other, ANOVA is robust with respect to non-normality (Glass \& Hopkins, 1996; Blanca et al., 2017).
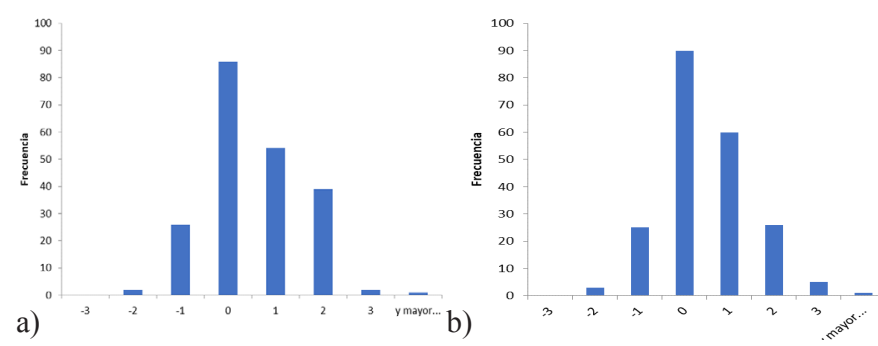

Figure 3. Histograms of aloin concentration residuals.

The second case requires that the aloin concentration residuals do not show a tendency (completely dispersed) with respect to the fresh mass (figure 4).

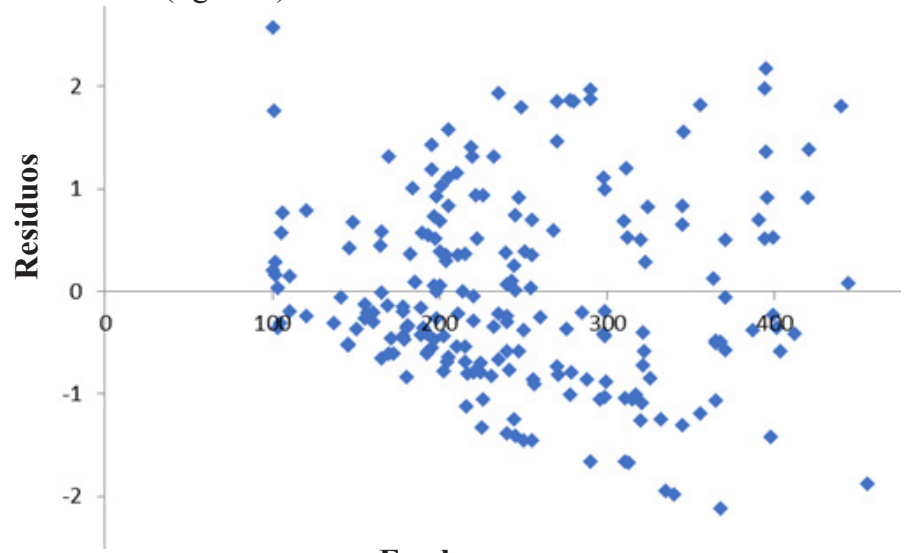

Fresh mass

Figure 4. Dispersion of the residual concentration of aloin regarding to the fresh mass.

For this purpose, the Durbin-Watson (DW) statistic was calculated for each model. For linear model 1, DW=1.493; for linear model 2, DW=1.490; for exponential model 1, DW=1.726; and for exponential model 2, DW=1.793.
The third assumption requires that homoscedasticity be respected. Similar to normality, when the size of the groups is equal, ANOVA is robust to heteroscedasticity (Statistics Solutions, 2013). The $\mathrm{p}$ value for the linear approximation model 1 (i.e., the model worked with the data classified with the class marks), is 0.551 and for the linear model 2 (i.e., the model worked with the data classified with the averages of the CA values in each class) is 0.563 . For the exponential approximation model 1 (the data classified with the class marks), the p-value found is 0.929 while for the exponential model 2 (with the averages of the CA values in each class) it is 0.857 . The models can be considered robust because they predict with acceptable accuracy the aloin concentration with the following coefficients of determination, $\mathrm{R}^{2}$; for the linear approximation models, with the data classified with the class marks (linear model 1$), \mathrm{R}^{2}=0.6540(\approx 65 \%)$ and with the data classified with the averages of the CA values in each class (linear model 2), $\mathrm{R}^{2}=0.6990(\approx 70 \%)$. For the exponential approximation models, with the data classified with the class marks (exponential model 1), $\mathrm{R}^{2}=0.8055(\approx 81 \%)$ and with the data classified with the averages of the CA values in each class (exponential model 2 ), $\mathrm{R}^{2}=0.8712$ $(\approx 87 \%)$.

Based on the previous analysis, the use of the exponential approximation mathematical model 2 is recommended to estimate or infer aloin concentration as a function of fresh mass only. This model is given by the equation of exponential approximation found:

$$
y=0.44886 e^{0.00458 x}
$$

where $\mathrm{x}$ represents the fresh mass $(\mathrm{PF})$ of the plant and $\mathrm{y}$ represents the aloin concentration.

In this research, the mathematical model did not discriminate the plants by their origin, but they were considered as belonging to a region that conglomerates all the populations into one.

The use of mathematical modeling to analyze the drying of $A$. vera leaves has been widely employed (Moradi et al., 2019; Sabat et al., 2018), as well as for the study of mass transfer during the gel rehydration phenomenon (Vega-Galvéz et al., 2009) and in the determination of optimal conditions for the removal of aloin from the gel (Martínez et al., 2017; Jawade \& Chavan, 2013), but no research is recorded on the application of these models to estimate the concentration of aloin, or any other secondary metabolite in Aloe spp. using only the fresh mass of the plant, so comparative studies of these results with those obtained in other works cannot be made. However, the robustness of the model was verified.

\section{Conclusions}

In this research, based on the mathematical modeling to estimate the concentration of aloin in $A$. vera $\mathrm{L}$., from the values of the fresh mass, it is concluded that the exponential curves found, approximate the data better than the calculated straight lines. Therefore, this model is recommended for the estimation of the aloin concentration in naturally propagated plants from their fresh mass and it can be used to carry out future investigations about the concentration of metabolites and other chemical compounds in plants of the Aloe genus by means of least squares approximations considering nonlinear polynomial functions. In the same way, this model is useful for the agricultural producer or interested person since it will be able to estimate the value of CA starting from an easy-tomeasure parameter, such as the fresh mass of the plant, without 
6-6 | Rev. Fac. Agron. (LUZ). 2022, 39(1): e223913. January - March. ISSN 2477-9407.

having to resort to laborious and expensive laboratory protocols and techniques, minimizing expenses and production stages.

\section{Cited literature}

Blanca, M., Alarcón, R., Arnau, J., Bono, R. \& Bendayan, R. (2017). Nonnormal data: Is ANOVA still a valid option? Psicothema 29(4): 552557. DOI: 10.7334/psicothema2016.383. PMID: 29048317.

Burden, R. \& Faires, D. (2011). Numerical Analysis. Brooks/Cole, Cengage Learning. United States. 1365p. Disponible en https://cutt.ly/rnoYMcW

Chapra, S. \& R. Canale. (2015). Métodos numéricos para Ingenieros. Editorial McGraw Hill. Séptima Edición. México. 977pp.

Charte, F. (2016). Microsoft Excel 2016. Manual Avanzado. Editorial Anaya Multimedia. $424 \mathrm{pp}$

Deng-Feng, X., Huan-Xi Y., Xie Chuan, P., Yi-Qi, D., Jun-Pei, C., Yan, Y., Song-Dong, Z. \& Xing-Jin, H. (2019). Phylogeny of chinese Allium species in section daghestanica and adaptive evolution of Allium (Amaryllidaceae, allioideae) species revealed by the chloroplast complete genome. Frontiers in Plant Science 10:460. DOI: https://doi. org/10.3389/fpls.2019.00460

Di Rienzo, J. ,Casanoves, F., Balzarini, M., Gonzalez, L., Tablada, M. \& Robledo, C.. (2011). InfoStat versión 2011. Grupo InfoStat. Universidad Nacional de Córdoba, Argentina. http://www.infostat.com.ar

Diario Oficial de las Comunidades Europeas. (1988). Directiva 88/388/CEE del Consejo de 22 de junio de 1988 relativa a la aproximación de las legislaciones de los Estados Miembros en el ámbito de los aromas que se utilizan en los productos alimenticios y de los materiales de base para su producción. https://cutt.ly/pnoY9y6.

Epperson, J. (2021). An introduction to numerical methods and analysis. Editorial Wiley \& Sons, Inc. Tercera edición. 385pp.

Ewel, J. y A. Madrid. 1976. Zonas de vida en Venezuela. Memorias explicativas sobre el mapa ecológico. Ministerio de Agricultura y Cría. Caracas. $264 \mathrm{p}$

FAUBA. Facultad de Agronomía de la Universidad de Buenos Aires. (2018) Los simuladores del agro. Sobre La Tierra. https://cutt.ly/KnoY48

Glass, G. \& Hopkins, K. (1996). Statistical methods in education and psychology. Tercera edición. Editorial Allen \& Bacon. Orlando, FL. Academic Press. 1563pp. González, L. (2017). Análisis exploratorio de datos. Una introducción a la estadística descriptiva y probabilidad. Universidad de Bogotá Jorge Tadeo Lozano. Facultad de Ciencias Naturales e Ingeniería. 342 pp. Disponible en https://cutt.ly/3noUdcf

Jawade, N. \& Chavanb, A. (2013). Ultrasonic-Assisted extraction of Aloin from Aloe vera gel. Proceeding Engineering 51: 487-493 DOI: https://doi. org/10.1016/j.proeng.2013.01.069

Kaparakou, E., Kanakis, C., Gerogianni, M., Maniati, M., Vekrellis, K., Skottic, E. \& Tarantilisa, P. (2020). Quantitative determination of aloin, antioxidant activity, and toxicity of Aloe vera leaf gel products from Greece. Journal of the Science of Food and Agriculture 101(2): 414423. DOI: https://doi.org/10.1002/jsfa. 10650
Klopper, R. \& Smith, G. (2013). Aloes of the world: When, where and who?. Aloe 50: 1 y 2: 44-52. Disponible en https://cutt.ly/wnoOuBj

Mahor, G. \& Ali, S. (2016). Recent update on the medicinal properties and use of Aloe vera in the treatment of various ailments. Bioscience Biotechnology Research Communications 9(2): 273-288. Disponible en https://cutt.ly/snoOzZs

Martínez, W., Vélez, M., Espitia R., Paternina-Arboleda, C., Paroddy. A. \& Paternina, L. (2017). Optimización del proceso de eliminación de aloína del gel fileteado mecánico de Aloe vera concentrado 10X. Revista Cumbres 3(2): 09 - 16. DOI: https://doi.org/10.48190/cumbres. v3n2a16

Martínez-Burgos, W., Bittencourt E., Rodrigues de Paula, D., Pedroni A., Medeiros, J., Molina D. \& Soccol, C. (2021). Hydrogen production by dark fermentation using a new low-cost culture medium composed of corn steep liquor and cassava processing water: Process optimization and scale-up. Bioresource Technology 320, Part B. https://doi. org/10.1016/j.biortech.2020.124370.

Minjares R. \& Femenia A. (2019). Aloe vera. En Mohammad Nabavi, S. \& Sánchez Silva., A. (Eds.) Nonvitamin and Nonmineral Nutritional Supplements. Academic Press. Estados Unidos. Págs. 145-152. DOI: https://doi.org/10.1016/B978-0-12-812491-8.00020-5

Molero, T., Ettiene, G. \& Viloria, M. (2016). Determinación de aloína en poblaciones de Aloe vera L. (= Aloe barbadensis M.) del occidente de Venezuela. Revista Multiciencias 16 (2): 143-152. Disponible en https://cutt.ly/DnoPoxe

Moradi, M., Niakousari, M. \& Khaneghah, A. (2019). Kinetics and mathematical modeling of thin layer drying of osmo-treated Aloe vera (Aloe barbadensis) gel slices. Journal Proceeding Engineering 42 (6). DOI: https://doi.org/10.1111/jfpe.13180

Pandey, A. \& Singh, S. (2016). Aloe Vera: A Systematic Review of its Industrial and Ethno-Medicinal Efficacy. International Journal of Pharmaceutical Research \& Allied Sciences 5(1): 21-33. Disponible en https://cutt. ly/8noHci3

Pedroza, A., Gómez, F., Samaniego-Gaxiola, J., Trejo, R. \& Ruiz, J. (2009). Caracterización del proceso de industrialización y comercialización de la sábila: estudio de caso. Revista Chapingo Serie Zonas Aridas 8:241246. Disponible en https://cutt.ly/NnoJkVe

Sabat, M., Patel, S. \& Kalne, A. (2018). Influence of temperature on drying kinetics of Aloe vera and its mathematical modeling. Current Journal of Applied Science and Technology 31(5): 1-10. DOI: https://doi. org/10.9734/CJAST/2018/45591

Statistics Solutions. (2013). ANOVA (Analysis of Variance). https://www. statisticssolutions.com/free-resources/directory-of-statistical-analyses/ anova/

Steel, R. \& J. Torrie. 1960. Principles and Procedures of Statistics with Special Reference to the Biological Sciences. Editorial McGraw Hill. Pág. 187, 287.

Sturges, H. (1926). The Choice of a Class Interval. Journal of the American Statistical Association 21(153): 65-66.

Vega-Gálvez, A., Notte-Cuello, E., Lemus-Mondaca, R. \& Miranda, L. (2009). Mathematical modelling of mass transfer during rehydration process of Aloe vera (Aloe barbadensis Miller). Food and Bioproducts Processing 87(4): 254-260. DOI: https://doi.org/10.1016/j.fbp.2008.10.004 